\title{
РОЗРОБКА СПЕКТРОФОТОМЕТРИЧНОЇ МЕТОДИКИ ВИЗНАЧЕННЯ СУМИ ФЛАВОНОЇДІВ В ЕКСТРАКТАХ ЧЕБРЕЦЮ ПОВЗУЧОГО
}

Вступ. На сьогодні помітно зростає науковий інтерес до вивчення фрлавоноїдів у лікарській рослинній сировині, що пов'язано з їх високою біологічною активністю та різноплановою фрармакологічною дією. Доступним і перспективним джерелом БАР є чебрець повзучий (ЧП). Як свідчать літературні дані, препарати на його основі широко використовують у народній і практичній медицині, що робить ЧП актуальним на сьогодні для розробки нових вітчизняних рослинних препаратів. Розробка нового муколітичного засобу на основі густого екстракту чП і ефрірної олії чебрецю звичайного передбачала одержання рідкого і густого екстрактів ЧП. За технологією отримано екстракти із задовільними фрармако-технологічними властивостями та максимальним і стабільним вмістом БАР досліджуваної сировини. 3 метою стандартизації трави ЧП як показник якості, серед інших, було обрано склад і вміст фрлавоноїдів та гідроксикоричних кислот. Складні комбінації БАР, що наявні в екстрактах, вимагають використання сучасних методів аналізу для їх стандартизації і в майбутньому - готового лікарського засобу, тому доречним $\epsilon$ проведення їх ідентифрікації та кількісного визначення. Після виконання якісного аналізу БАР у цих екстрактах необхідно визначити також їх кількісний вміст, що дозволить запропонувати кількісний показник якості та обрати критерії прийнятності.

Мета дослідження - розробити методику кількісного визначення суми фрлавоноїдів у рідкому і густому екстрактах чебрецю повзучого та обрати відповідні критерії прийнятності.

Методи дослідження. У цьому дослідженні використовували спектрофотометр марки "Сагу-50", (ФС3) апігенін (Fluka), екстракти чебрецю повзучого, етиловий спирт 60 \% (об/об), 3 \% розчин алюмінію хлориду $P$.

Результати й обговорення. Вміст фрлавоноїдів в одержаних екстрактах ЧП визначали методом диференціальної спектрофотометрії за реакцією утворення фотометрованої сполуки з алюмінію хлоридом. Кількісний вміст фрлавоноїдів у досліджуваних екстрактах ЧП коливався у певних межах і визначався їх вмістом у вихідній сировині та відтворюваністю технології екстракту. Для їх стандартизації можна запропонувати кількісним критерієм якості вміст фрлавоноїдів: для рідкого екстракту - не менше 0,03 \%, для густого - не менше 2,5 \% у перерахунку на апігенін.

Висновки. Розроблено методику кількісного визначення суми фрлавоноїдів у екстрактах чебрецю повзучого. У результаті визначено їх кількісний вміст та запропоновано критерії прийнятності.

КЛЮчОВІ СЛОВА: чебрець повзучий; фрлавоноїди; екстракти; кількісне визначення; спектрофотометрія; критерії прийнятності.

ВСТУП. Перспективною ЛРС для розробки нових вітчизняних рослинних препаратів залишається чебрець повзучий (ЧП), який природно розповсюджений на території України в дикому вигляді та широко культивується [1-4]. Згідно 3 джерелами літератури, препарати на його основі широко використовують у народній та науковій медицині при захворюваннях верхніх дихальних шляхів [1-5].

Розробка нового муколітичного засобу на основі густого екстракту ЧП і есрірної олії чебрецю звичайного передбачала розробку технології рідкого і густого екстрактів чебрецю повзучо(c) H. О. Зарівна, 2020 го. У попередніх дослідженнях було підібрано оптимальні умови екстракції та режими згущення, що дозволило в короткий термін отримати екстракти з максимальним і стабільним вмістом БАР досліджуваної сировини та із задовільними срармако-технологічними показниками якості $[6,7]$. Для проведення стандартизації рослинних препаратів, а також напівпродуктів, що містять складний комплекс БАР [8], доречно застосовувати сучасні методи аналізу, які характеризуються високою чутливістю, селективністю тощо [9].

Мета дослідження - розробити методику кількісного визначення суми срлавоноїдів у рід- 
кому і густому екстрактах чебрецю повзучого та обрати відповідні критерії прийнятності.

МЕТОДИ ДОСЛІДЖЕННЯ. У цЬОМУ дослідженні використовували метод диференціальної спектрофотометрії, застосовуючи спектросоотометр марки "Cary-50", за реакцією утворення фотометрованої сполуки з алюмінію хлоридом.

РЕЗУЛЬТАТИ Й ОБГОВОРЕННЯ. СУМУ фрЛавоноїдів в одержаних екстрактах ЧП визначали методом диференціальної спектрофотометрії за реакцією утворення фотометрованої сполуки 3 алюмінію хлоридом [10-12]. Як компенсаційний розчин використовували вихідний розчин без додавання відповідних реактивів, що унеможливило вплив забарвлених та супутніх речовин. Найбільш повне вилучення суми фрлавоноїдів із трави чебрецю здійснювали за умов отримання спиртових вилучень при застосуванні спирту (60-70\% (об/об)), а при підвищенні концентрації спирту в екстрагенті вміст фрлавоноїдів не зростав, що, опосередковано, вказувало на наявність як агліконових, так і глікозидних фрорм фрлавоноїдів у досліджуваній сировині [8]. Це дозволило для пробопідготовки спектрофотометричного визначення суми фрлавоноїдів використати $70 \%$ (об/об) спирт етиловий. Стандартом для розрахунку кількісного вмісту фрлавоноїдів у сировині ЧП було обрано апігенін, тому і при контролі якості досліджуваних екстрактів необхідно розраховувати кількість фрлавоноїдів у перерахунку на апігенін [8, 12].

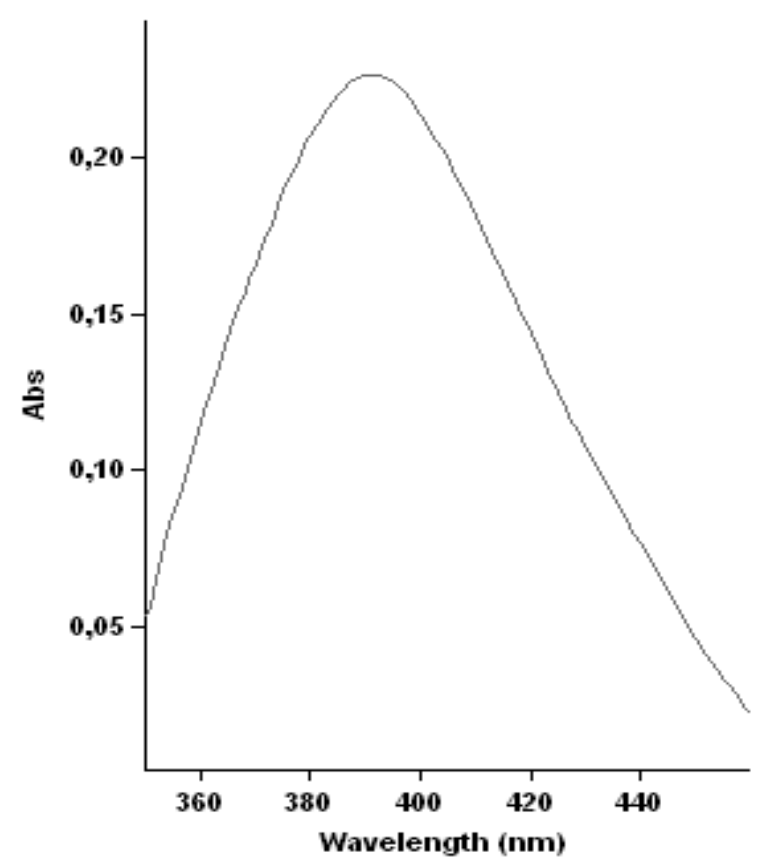

a
Диференціальні електронні спектри поглинання комплексу алюмінію хлориду з фрлавоноїдами, наявними в рідкому екстракті чП, характеризувалися наявністю максимуму поглинання при (390 2$)$ нм (рис.).

Як видно з рисунка, за умов кількісного визначення фрлавоноїдів спектр поглинання випробуваного розчину для досліджуваного екстракту чебрецю повзучого за ходом кривої та положенням максимуму відповідає спектру поглинання відповідного комплексу апігеніну, тому суму фрлавоноїдів в екстракті розраховували в перерахунку на апігенін. Для визначення суми срлавоноїдів у рідкому та густому екстрактах ЧП було запропоновано таку методику.

Методика визначення суми флавоноїдів у рідкому і густому екстрактах чебрецю повзучого.

Вихідний розчин (а). 10,0 мл рідкого екстракту ЧП поміщають у мірну колбу місткістю 50 мл і доводять об'єм розчину спиртом (70\%, об/об) Р до позначки, перемішують (вихідний розчин).

Випробуваний розчин (а). 1,0 мл вихідного розчину (a) поміщають у мірну колбу місткістю 25 мл, додають 2,0 мл 3 \% розчину алюмінію хлориду і доводять об'єм розчину спиртом (70 \%, об/об) Р до позначки, перемішують.

Компенсаційний розчин. 1,0 мл вихідного розчину (а) поміщають у мірну колбу місткістю 25 мл і доводять об'єм розчину спиртом (70 \%, об/об) Р до позначки, перемішують.

Вихідний розчин (б). 0,13 г (точна наважка) густого екстракту ЧП поміщають у мірну колбу

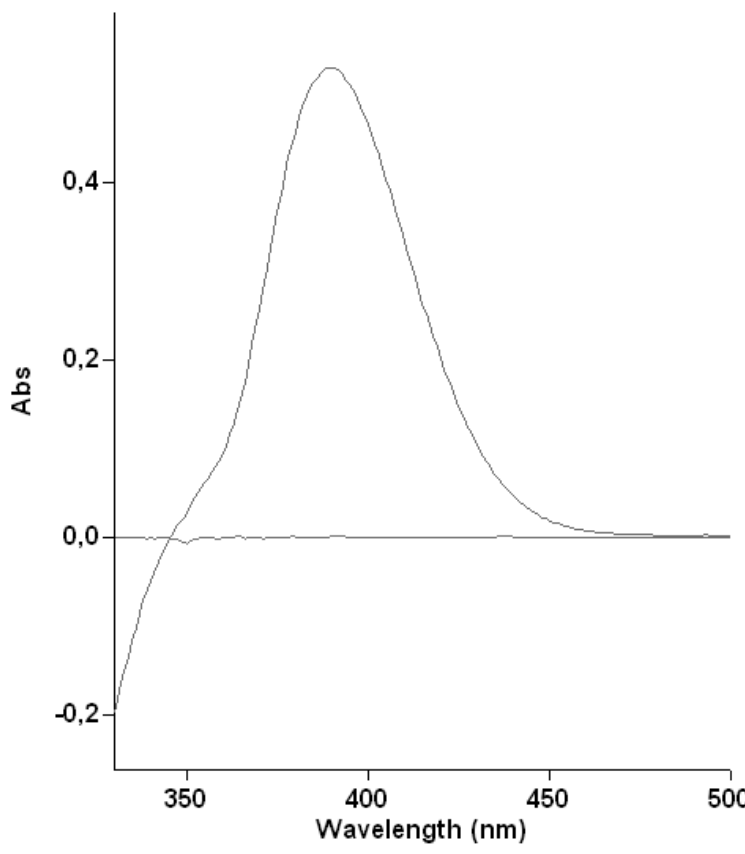

6

Рис. Диференціальні електронні спектри поглинання випробуваного (а) і розчину порівняння (б) за умов кількісного визначення фрлавоноїдів у рідкому екстракті чебрецю повзучого ( $\lambda_{\max }=390,0$ нм). 
місткістю 25 мл, розчиняють у 20,0 мл спирту (70 \%, об/об) Р і доводять об'єм розчину тим же спиртом до позначки, перемішують.

Випробуваний розчин (б). 1,0 мл вихідного розчину (б) поміщають у мірну колбу місткістю 25 мл, додають 2,0 мл 3 \% розчину алюмінію хлориду і доводять об'єм розчину спиртом (70 \%, об/об) Р до позначки, перемішують.

Компенсаційний розчин. 1,0 мл вихідного розчину (б) поміщають у мірну колбу місткістю 25 мл і доводять об'єм розчину спиртом (70 \%, об/об) $P$ до позначки, перемішують.

Розчин стандартного зразка апігеніну. 0,03 г (точна наважка) стандартного зразка апігеніну (Fluka) поміщають у мірну колбу місткістю 100 мл, додають 70 мл спирту (70 \%, об/об) P, розчиняють і доводять об'єм розчину тим самим розчинником до позначки, перемішують.

10,0 мл отриманого розчину поміщають у мірну колбу місткістю 25 мл і доводять об'єм розчину спиртом (70 \%,об/об) Р до позначки, перемішують.

Розчин порівняння. 1,0 мл розчину стандартного зразка апігеніну поміщають у мірну колбу місткістю 25 мл, додають 2,0 мл $3 \%$ розчину алюмінію хлориду і доводять об'єм розчину спиртом (70\%, об/об) Р до позначки, перемішують.

Компенсаційний розчин. 1,0 мл розчину стандартного зразка апігеніну поміщають у мірну колбу місткістю 25 мл і доводять об'єм розчину спиртом (70 \%, об/об) Р до позначки, перемішують.
Через 45 хв записують дисреренціальні електронні спектри поглинання для випробуваного розчину і розчину порівняння відносно компенсаційних розчинів для кожного відповідно та вимірюють оптичну густину в максимумі поглинання при довжині хвилі $(390 \pm 2)$ нм.

Вміст суми фрлавоноїдів $\left(\mathrm{X}_{1}\right)$ в рідкому екстракті чебрецю повзучого, у відсотках у перерахунку на апігенін, розраховують за фрормулою:

$$
\mathrm{X}_{1}=\frac{2 \cdot \mathrm{m}_{0} \cdot \mathrm{A}}{\mathrm{A}_{0}}
$$
чину;

де A - оптична густина випробуваного роз-

$\mathrm{m}_{\mathrm{o}}$ - маса наважки стандартного зразка апігеніну, г;

$\mathrm{A}_{0}$ - оптична густина розчину порівняння.

Вміст суми фрлавоноїдів $\left(\mathrm{X}_{2}\right)$ в густому екстракті чебрецю повзучого, у відсотках у перерахунку на апігенін та суху речовину, розраховують за фрормулою:

$$
\mathrm{X}_{2}=\frac{25 \cdot \mathrm{m}_{0} \cdot 6 \cdot 100 \cdot 100 \cdot \mathrm{A}}{\mathrm{A}_{0} \cdot 100 \cdot \mathrm{m} \cdot(100-\mathrm{W})}
$$

де A - оптична густина випробуваного розчину;

m - маса наважки екстракту, взятого для аналізу, г;

$\mathrm{m}_{0}$ - маса наважки стандартного зразка апігеніну, г;

W - втрата в масі при висушуванні, \%.

Результати кількісного визначення суми фрлавоноїдів у рідкому і густому екстрактах наведено в таблиці.

Таблиця - Результати визначення вмісту флавоноїдів у рідкому і густому екстрактах $(P=0,95, n=5)$

\begin{tabular}{||c|c|c|c|c|}
\hline \multirow{2}{*}{ Екстракт } & \multicolumn{4}{|c|}{ Вміст фолавоноїдів у перерахунку на апігенін, \% } \\
\cline { 2 - 5 } & № 1 & № 2 & № 3 & № 4 \\
\hline Рідкий екстракт чебрецю повзучого & $0,052 \pm 0,010$ & $0,049 \pm 0,010$ & $0,051 \pm 0,010$ & $0,048 \pm 0,010$ \\
\hline Густий екстракт чебрецю повзучого & $2,810 \pm 0,010$ & $2,800 \pm 0,020$ & $2,810 \pm 0,030$ & $2,770 \pm 0,020$ \\
\hline
\end{tabular}

Кількісний вміст фрлавоноїдів у досліджуваних екстрактах ЧП коливається у певних межах і визначається їх вмістом у вихідній сировині та відтворюваністю технології екстракту. Зважаючи на одержані результати кількісного визначення, при стандартизації отриманих екстрактів чебрецю повзучого можна запропонувати кількісним критерієм якості вміст фрлавоноїдів: для рідкого екстракту - не менше $0,03 \%$, для густого - не менше 2,5\% у перерахунку на апігенін. Кореляція вмісту основних груп БАР свідчить про коректність вибраних умов переведення рідкого екстракту в густий.

ВИСНОВКИ. 1. Розроблено спектрофротометричну методику кількісного визначення срлавоноїдів у досліджуваних екстрактах чебрецю повзучого.

2. 3 метою стандартизації досліджуваних екстрактів чебрецю повзучого запропоновано кількісний критерій якості: вміст фрлавоноїдів не менше 0,03 \% для рідкого екстракту, не менше 2,5 \% - для густого в перерахунку на апігенін. 


\section{СПИСОК ЛІТЕРАТУРИ}

1. Биологическая активность растительных источников фрлавоноидов / А. В. Крикова, Р. С. Давыдов, Ю. Н. Мокин [и др.] // Фармация. - 2006. - 54, № 3. C. $17-18$.

2. Грущенко Л. Чебрецевий рай. Високі технології Лубенської дослідної станції лікарських рослин Інституту агроекології УААН / Л. Грущенко, В. Рак // Фармацевт - практик : наук.-попул. та станово-побутовий журн. - 2010. - № 9. - С. 26-28.

3. Thyme oil. Monograph N: 1374.Concerned also monograph N 865 (Thymi herba) and N 1891 (Serpylli herba). - PA/PH/ Exp. 13A/T (09) 351 R. - Strasbourg: European Department for the Quality of Medicines, April 2009.

4. Kohlmünzer Stanisław. Farmakognozja Podręcznik dla studentów farmaciji i Wydanie $v$ unowocześ nione I Stanisław Kohlmünzer. - Warszawa: Wydownictwo Lea karskie PZWL, 2007. - 669 s.

5. Соколов С. Я. Фитотерапия и фитофрармакология : руководство для врачей / С. Я. Соколов. - М. : МИА, 2000. - 976 c.

6. Пат. 73543 Україна, МПК ${ }^{51}$ C 11 В 1/10, А 61 K 9/08, А 61 К 35/00. Спосіб отримання рідкого екстракту чебрецю повзучого / Зарівна Н. О., Вронська Л. В., Грошовий Т. А. ; заявник і патентовласник Терноп. держ. мед. ун-т імені І. Я. Горбачевського. - Заявл. 26.03.12 ; опубл. 25.09.12, Бюл. № 18.

\section{REFERENCES}

1. Krykova, A.V. (2006). Biologicheskaya aktivnost rastitelnykh istochnikov flavonoidov [Biological activity of flavonoid plant sources]. Farmatsiya - Pharmacy, 54 (3), 17-18 [in Russian].

2. Hrushchenko, L., \& Rak, V. (2010). Chebretsevyi rai. Vysoki tekhnolohii Lubenskoi doslidnoi stantsii likarskykh roslyn Instytutu ahroekolohii UAAN [Thyme paradise. High technologies of Lubensk Medicinal Plants Research Station of the Institute of Agroecology of the UAAS]. Farmatsevt - praktyk: nauk.-popul. ta stanovopobutovyi zhurn. - Pharmacist - Practitioner: Popular Science and Estate Journal, 9, 26-28 [in Ukrainian].

3. (2009). Thyme oil. Monograph N: 1374.Concerned also monograph N 865 (Thymi herba) and N 1891 (Serpylli herba). - PA/PH/ Exp. 13A/T (09) 351 R. - Strasbourg: European Department for the Quality of Medicines.

4. Kohlmünzer Stanisław (2007). Farmakognozja Podręcznik dla studentów farmaciji i Wydanie $v$ unowocześ nione. Warszawa: Wydownictwo 5. Lekarskie PZWL.

5. Sokolov, S.Ya. (2000). Fitoterapiya i fitofarmakologiya: rukovodstvo dlya vrachey [Phytotherapy and phytopharmacology: a guide for doctors]. Moscow: MIA [in Russian].

6. Zarivna, N.O., Vronska, L.V., \& Hroshovyi, T.A. (2012). Pat. Ukrainy, Sposib otrymannia ridkoho ekstrakf tu chebretsiu povzuchoho [The method of obtaining liquid creeping thyme extract]. No. 73543 MPK51 S 11 V 1/10, A 61 K 9/08, A 61 K 35/00; Biul. No. 18 [in Ukrainian].
7. Зарівна Н. О. Вивчення режимів згущення при одержанні густого екстракту чебрецю повзучого / Н. О. Зарівна // Мед. та клініч. хімія. - 2019. - 21, № 4 (82). - C. 134-141.

8. Зарівна Н. О. До питання стандартизації трави чебрецю повзучого за вмістом фрлавоноїдів / Н. О. Зарівна, Л. В. Вронська // Управління, економіка та забезпечення якості в фрармації. - 2012. - № 5 (25). С. 21-27.

9. Настойки, экстракты, эликсиры и их стандартизация / под ред. В. Л. Багировой, В. А. Северцева. СПб. : Спец. Лит., 2001. - 223 с.

10. Державна Фармакопея України : в 3 т. / Державне підприємство "Український науково-експертний фармакопейний центр якості лікарських засобів". 2-ге вид. - Харків : Державне підприємство "Український науково-експертний фрармакопейний центр якості лікарських засобів". - 2015. - 1. - 1128 с.

11. Bazylko Agnieszka Badania porownawcze flawonoidow zawartych w Thymi herba et extracta / Agnieszka Bazylko, Halina Strzelecka // II Konferencia Flavonoidy i ich zastosowanie. - Rheszow, 1998. S. 238.

12. Зарівна Н. О. Стандартизація рідкого екстракту чебрецю повзучого / Н. О. Зарівна, Л. В. Вронська // Укр. біофармац. журн. - 2012. - № 5-6. - С. 108-112.

7. Zarivna, N.O. (2019). Vyvchennia rezhymiv zhushchennia pry oderzhanni hustoho ekstraktu chebretsiu povzuchoho [The study of the modes of condensation in obtaining a thick creeping thyme extract]. Medychna ta klinichna khimiia - Medical and Clinical Chemistry, 4 (21), 134-141 [in Ukrainian].

8. Zarivna, N.O., \& Vronska, L.V. (2012). Do pytannia standartyzatsii travy chebretsiu povzuchoho za vmistom flavonoidiv [On the standardization of thyroid creeping by the content of flavonoids]. Upravlinnia, ekonomika ta zabezpechennia yakosti v farmatsii - Management, Economics and Quality Assurance in Pharmacy, 5 (25), 21-27 [in Ukrainian].

9. Bagirova, V.L., \& Severtseva, V.A. (Eds.). (2001). Nastoyky, ekstrakty, eliksiry i ikh standartyzatsiya [Tinctures, extracts, elixirs and their standardization]. SaintPetersburg: Spets. Lit [in Russian].

10. (2015). Derzhavna Farmakopeia Ukrainy: $v 3 t$. [State Pharmacopoeia of Ukraine:in 3 vol.]. State Enterprise "Ukrainian Scientific Pharmacopoeia Center for the Quality Medicines" [in Ukrainian].

11. Bazylko Agnieszka (1998). Badania porownawcze flawonoidow zawartych w Thymi herba et extracta. II Konferencia Flavonoidy i ich zastosowanie, Rheszow.

12. Zarivna, N.O., \& Vronska, L.V. (2012). Standartyzatsiia ridkoho ekstraktu chebretsiu povzuchoho [Stant dardization of liquid creeping thyme extract]. Ukrainskyi biofarmatsevtychnyi zhurnal-Ukrainian Biopharmaceutical Journal, 5-6, 108-112 [in Ukrainian]. 


\section{РАЗРАБОТКА СПЕКТРОФОТОМЕТРИЧЕСКОЙ МЕТОДИКИ ОПРЕДЕЛЕНИЯ СУММЫ ФЛАВОНОИДОВ В ЭКСТРАКТАХ ТИМЬЯНА ПОЛЗУЧЕГО}

\section{Резюме}

Вступление. На сегодня заметно возрастает научный интерес к изучению фрлавоноидов в лекарственном растительном сырье, что связано с их высокой биологической активностью и разноплановым орармакологическим действием. Доступным и перспективным источником БАВ остается тимьян ползучий (ТП). Как свидетельствуют литературные данные, препараты на его основе широко используют в народной и практической медицине, что делает ТП актуальным сегодня для разработки новых отечественных растительных препаратов. Разработка нового муколитического средства на основе густого экстракта ТП и эфирного масла тимьяна обыкновенного предполагала получение жидкого и густого экстрактов ТП. По технологии получены экстракты с удовлетворительными фрармако-технологическими свойствами и максимальным и стабильным содержанием БАВ исследуемого сырья. С челью стандартизации травы ТП как показатель качества, среди прочих, было выбрано состав и содержание фрлавоноидов и гидроксикоричных кислот. Сложные комбинации БАВ, что присутствуют в экстрактах, требуют использования современных методов анализа для их стандартизации и в будущем - готового лекарственного средства, поэтому уместно проведение их идентификации и количественного определения. После выполнения качественного анализа БАВ в этих экстрактах необходимо определить также их количественное содержание, что позволит предложить количественный показатель качества и выбрать критерии приемлемости.

Цель исследования - разработать методику количественного определения суммы фрлавоноидов в жидком и густом экстрактах тимьяна ползучего и выбрать соответствующие критерии приемлемости.

Методы исследования. В этом исследовании использовали спектрофотометр марки “Сary-50", (ФСО) апигенин (Fluka), экстракты тимьяна ползучего, этиловый спирт 60 \% (об/об), 3 \% раствор алюминия хлорида $P$.

Результаты и обсуждение. Содержание фрлавоноидов в полученных экстрактах ТП определяли методом дифрференциальной спектрофротометрии по реакции образования фротометрируемого соединения с алюминия хлоридом. Количественное содержание фрлавоноидов в исследуемых экстрактах ТП колебалось в определенных пределах и определялось их содержанием в исходном сырье и воспроизводимостью технологии экстракта. Для их стандартизации можно предложить количественным критерием качества содержание фрлавоноидов: для жидкого экстракта - не менее 0,03 \%, для густого - не менее 2,5\% в пересчете на апигенин.

Выводы. Разработана методика количественного определения суммы фрлавоноидов в экстрактах тимьяна ползучего. В результате определено их количественное содержание и предложены критерии приемлемости.

КЛЮЧЕВЫЕ СЛОВА: тимьян ползучий; фрлавоноиды; экстракты; количественное определение; спектрофотометрия; критерии приемлемости.

N. O. Zarivna

I. HORBACHEVSKY TERNOPIL NATIONAL MEDICAL UNIVERSITY

\section{DEVELOPMENT OF A SPECTROPHOTOMETRIC METHOD OF DETERMINATION OF SUM OF FLAVONOIDS IN THYME CREEPING EXTRACTS}

\section{Summary}

Introduction. Nowadays, there is a growing scientific interest in the study of flavonoids in medicinal plant raw material, which is associated with their high biological activity and diverse pharmacological action [1]. An accessible and promising source of biologically active substances is the well-known thyme creeping (TC). Analyzing the literary data, medicines based on it are widely used in folk and practical medicine, which makes thyme creeping relevant for the development of new domestic plant extracts. The development of a new mucolytic means on the basis of thick extract of thyme creeping and essential oil of thyme ordinary envisaged the receipt of liquid and thick thyme 
creeping extract. Last one got on technology, which resulted in extracts with satisfactory pharmaco-technological properties and maximum and stable content of BAS of the studied raw material. In previous researches the analysis of thyme creeping was conducted, and, in order to standardize this raw material as an indicator of quality and among others, the composition and content of flavonoids and hydroxycitric acids was chosen. The complex combinations of BASs available in extracts require the use of modern methods of analysis for their standardization and, in the future, ready-to-use medical products extracts. After realization of quality analysis of flavonoids and hydroxybutyric acids in these extracts, it is also necessary to define their quantitative content, that will allow to offer a quantitative index therefore appropriate is realization of authentication and quantitative determination of investigated BAS aS basic indexes of quality of the quality and acceptability criteria in carrying out the standardization of the received extracts of TC.

The aim of the study - to work out methodology of quantative determination of flavonoids in liquid and thick (TC) extracts and to select appropriate acceptability criteria.

Research Methods. Cary-50 spectrophotometer, (FSZ) apigenin (Fluka), liquid and thick thyme creeping extract, ethyl alcohol 60\% ( $/ \mathrm{V})$, $3 \%$ aluminum chloride solution $R$ were used in the study.

Results and Discussion. The content of flavonoids in the obtained TC extracts was determined by differential spectrophotometry by the reaction of formation of a photometer compound with aluminum chloride. The quantitative content of flavonoids in the investigated TC extracts varies within certain limits and is determined by their content in the feedstock and reproducibility of the extract technology. For the standardization of the got thyme creeping extracts it is possible to offer quantitative quality criteria of flavonoids content not less than $0.03 \%$, thick extract - not less than $2.5 \%$ in terms of apigenin.

Conclusions. A method for quantifying the amount of flavonoids in thyme creeping extracts was worked out. As a result, their quantitative content is determined and acceptability criteria were proposed. criteria.

KEY WORDS: thyme creeping; flavonoids; extract; quantification; spectrophotometry; acceptability

Отримано 15.04.20

Адреса для листування: Н. О. Зарівна, Тернопільський національний медичний університет імені І. Я. Горбачевського МОз України, майдан Волі, 1, Тернопіль, 46001, Україна, e-mail: zarivna@tdmu.edu.ua. 